Vol. 3, No. 1, 2021

https://doi.org/10.23939/jtbp2021.01.029

Yuriy Furdas $^{1}$, Khrystyna Kozak ${ }^{1}$, Olena Savchenko ${ }^{1}$, Mariia Lunyk ${ }^{1}$, Mykola Hensetskyi ${ }^{2}$

\title{
THE USE OF AGRICULTURAL BIOMASS AS A SOURCE FOR BIOGAS PRODUCTION
}

\author{
Lviv Polytechnic National University, \\ ${ }^{1}$ Department of Heat, Gas Supply and Ventilation, \\ cr_i $@$ @ukr.net \\ ${ }^{2}$ Technical and Economic College, \\ Lviv Polytechnic National University
}

(C) Furdas Yu., Kozak K., Savchenko O., Lunyk M., Hensetskyi M., 2021

As raw materials in bioenergy can be used agricultural residues formed in the process of harvesting crops and in the process of their processing, in particular straw cereals, legumes, corn and sunflower seeds, etc. For energy needs, agricultural biomass is used by burning or processing into solid, liquid or gaseous fuels. In the production of gaseous fuel in special plants - bioreactors, from agricultural waste is formed not only a source of energy - biogas, but also excellent fertilizers.

In this article, studies have shown that the amount of biogas produced depends on the type of biomass and fermentation time. The largest amount of biogas is produced within 10 days from the date of loading of organic biomass. It was found that the highest daily biogas production is formed from grass and grain silage, the maximum value of which is $1.76 \mathrm{~m}^{3}$. The smallest - from rapeseed silage $-0.33 \mathrm{~m}^{3}$.

Key words: biomass, biogas, bioreactor, agricultural biomass, fermentation time, bioenergy.

\section{Introduction}

Ukraine has significant amounts of land resources for agricultural production. It is able not only to provide its people with food, but also to produce raw materials for bioenergy. The main source of energy in bioenergy is biomass, that is, recovered organic matters that can be biodegradable. The waste and the remnants from agriculture, wood waste in forestry, woodworking and pulp and paper industry, energy crops, organic parts of industrial and household waste are used as biomass (Chernukha et. al., 2016; Savchenko et. al., 2018). The use of biomass has several advantages: it is a renewable energy source; its use will reduce the amount of waste from various sectors of the economy, during combustion of biomass does not produce gases that contribute to the greenhouse effect, and thus improves the environmental status of the environment. At present, the share of renewable energy sources in the energy balance of Ukraine is negligible at 3-4\%, but the amount of biomass in renewable energy sources can be up to $20 \%$. In Ukraine, the first place in the use of biomass is wood - $88 \%$. Another important component of the biomass potential in Ukraine is agricultural waste of crop and livestock. Crop waste is divided into primary and secondary (Litvak, 2015). Primary agricultural waste includes straw of cereals, legumes, corn and corn grain waste and sunflower. They are formed directly in the process of harvesting the crops concerned. Secondary agricultural waste includes waste that is formed during the processing of harvest (sunflower husk, rice peel, pulp of sugar beet, etc.) (Soroka et. al., 2016).

For the production of thermal or electric energy biomass from agricultural waste is used directly by burning or by processing into solid, liquid or gaseous fuels.

The easiest way to get useful energy from biomass is direct burning. The main drawbacks of this method are the difficulties associated with the provision of automatic fueling, the need for constant 
attention from users, the pollution of the environment with smoke and soot, that is, requires a special design of boilers (Bodnar et. al., 2015).

The agricultural biomass that is pelletized or briquettes is used as a solid biofuel (Niedziolka and Dakhnovskaya, 2014). The process of pellet formation takes place in pelletizing presses and consists of pressing the crushed biomass into the compression channel as a result of the interaction of the roller and the material layer between the roller and the matrix. Wood, husk, straw and reeds are used as raw materials in the fuel briquettes production, which is pressed in press-brackets.

To liquid biofuels are bioethanol and biodiesel (Gelotukha et. al., 2011). The raw material for bioethanol production is products containing starch, sugar or cellulose. Biodiesel fuel is a product of the transesterification of plant oils and is a mixture of methyl or ethyl esters of fatty acids. It can be used in its pure form, or as a mixture with conventional diesel fuel in any proportions. Raw materials for it are plant oils.

The production and use of biogas is an effective way of supplementing and replacing traditional fuel and energy resources. Biogas is very convenient to use and is used on decentralized block heating plants for electricity supply and heat supply or can be supplied to an existing gas transmission network.

\section{The purpose of the article}

The aim of the article is to investigate the amount of biogas output from different agricultural biomass with a variable period of its loading into the bioreactor.

\section{Methology}

Biogas is a flammable multicomponent gas consisting of methane (50-75\%), carbon dioxide (25$50 \%)$, water vapor $(0-10 \%)$, nitrogen $(0.01-5 \%)$, oxygen $(0.01-2 \%)$, hydrogen $(0-1 \%)$, ammonia $\left(0.01-2.5 \mathrm{mg} / \mathrm{m}^{3}\right)$ and hydrogen sulfide $\left(10-30 \mathrm{mg} / \mathrm{m}^{3}\right.$ ) (Panchuk and Shlapak, 2016), (Guangtao Wang, 2010). Biogas is formed as a result of anaerobic (without access to oxygen) decomposition of organic biomass. The process of biogas production takes place in four stages (Perederiy, 2008):

1. The stage of hydrolysis (splitting) of complex biopolymer molecules into simpler oligo- and monomers.

$$
\left[\mathrm{C}_{6} \mathrm{H}_{10} \mathrm{O}_{5}\right] \mathrm{n}+\mathrm{nH}_{2} \mathrm{O}=\mathrm{nC}_{6} \mathrm{H}_{12} \mathrm{O}_{6}
$$

2. The fermentation stage: the oxidation of the monomers formed in the first stage to the more simple substances, while carbon dioxide and hydrogen are also formed.

3. Acetogenic stage - the reproduction of acid-forming bacteria, in which the direct precursors of methane are formed: acetate, hydrogen, carbon dioxide.

$$
\mathrm{C}_{6} \mathrm{H}_{12} \mathrm{O}_{6}+2 \mathrm{H}_{2} \mathrm{O}=2 \mathrm{CH}_{3} \mathrm{COOH}+2 \mathrm{CO}_{2}+4 \mathrm{H}_{2}
$$

4. The methanogenic stage is the multiplication of methane-forming bacteria, which leads to the receipt of the final product - methane.

$$
\begin{gathered}
\mathrm{CH}_{3} \mathrm{COOH}=\mathrm{CH}_{4}+\mathrm{CO}_{2} \\
4 \mathrm{CH}_{4}+\mathrm{CO}_{2}=\mathrm{CH}_{4}+2 \mathrm{H}_{2} \mathrm{O}
\end{gathered}
$$

The amount of biogas yield is influenced by four groups of factors: biological (type of biomass its organic and moisture composition, microflora composition, living conditions of microorganisms), physical (fermentation temperature, pressure in the biogas plant, hydraulic regime), chemical (concentration, acidity, content) volatile fatty acids in the biomass, the volume and composition of biogas produced) and organizational and technological (dose of daily loading of new portions of organic matter, the load on the ash substance, residual substances, the presence of the mixing process of raw materials, etc.).

Anaerobic fermentation of organic matter occurs in biogas plants, the main element of which is a bioreactor. Constructions of bioreactors are quite diverse and are differ:

- from form of the reactor: egg-shaped, cylindrical, trench, cubic, elastic;

- from reservoir placement: with a horizontal or vertical reservoir; 
- by the number of chambers: one-chamber and two-chamber;

- from construction material : concrete, glassplastic, metal;

- from mixing method: with mechanical, hydraulic or bubbling mixing;

- from method of heat exchange: heating by hot water, heating by steam, electric heating;

- from volume of processing raw materials: centralized and individual.

When choosing the shape, size and design of a bioreactor, the following factors are considered first and foremost: the mass flow rate of the substrate when filling; the given biogas output or the degree of fermentation of the substrate as a function of the concentration of dry matter, loading of the working space, the time of the digestion cycle and the intensity of mixing; used production system; level of mechanization.

For the production of biogas, you can use any organic biomass, and the technology of anaerobic fermentation can obtain a source of energy in the form of biogas, high quality fertilizers and proteinvitamin feed additives, as well as solves environmental problems in agriculture.

\section{Results}

Despite the unstable situation in the energy sector and a significant amount of biomass in Ukraine, the percentage of use of agricultural residues as an energy resource does not exceed $2 \%$. In the process of harvesting, the grain part of the agricultural plant is separated from the stem, with part of the straw is collected, and the other - remains in the form of stubble in the field. The collected straw can be used for livestock (underlay and rough livestock feed), as organic fertilizer, for growing mushrooms in closed soil.

The unutilized remnants in Ukraine is often burned in the fields, which leads to the destruction and degeneration of organic matter of the soil, the strengthening of erosion and deflationary danger, the destruction of stubble residues as organic fertilizers and sources of organic matter remediation, the destruction of the natural fauna of the soil and soil microbiological fauna, air pollution basin by products of burning stubble and straw.

Among the waste of plants that bring the greatest energy potential are straw of grain crops, corn waste (stems, leaves) and sunflower waste (stems, baskets), therefore it is expedient to use them as an alternative source of energy in bioenergy (Zhelykh and Furdas, 2011).

For the production of biogas from crop residues, a bioreactor design was developed, the scheme and general view of which is shown in Fig. 1 (Xue et. al., 2017).
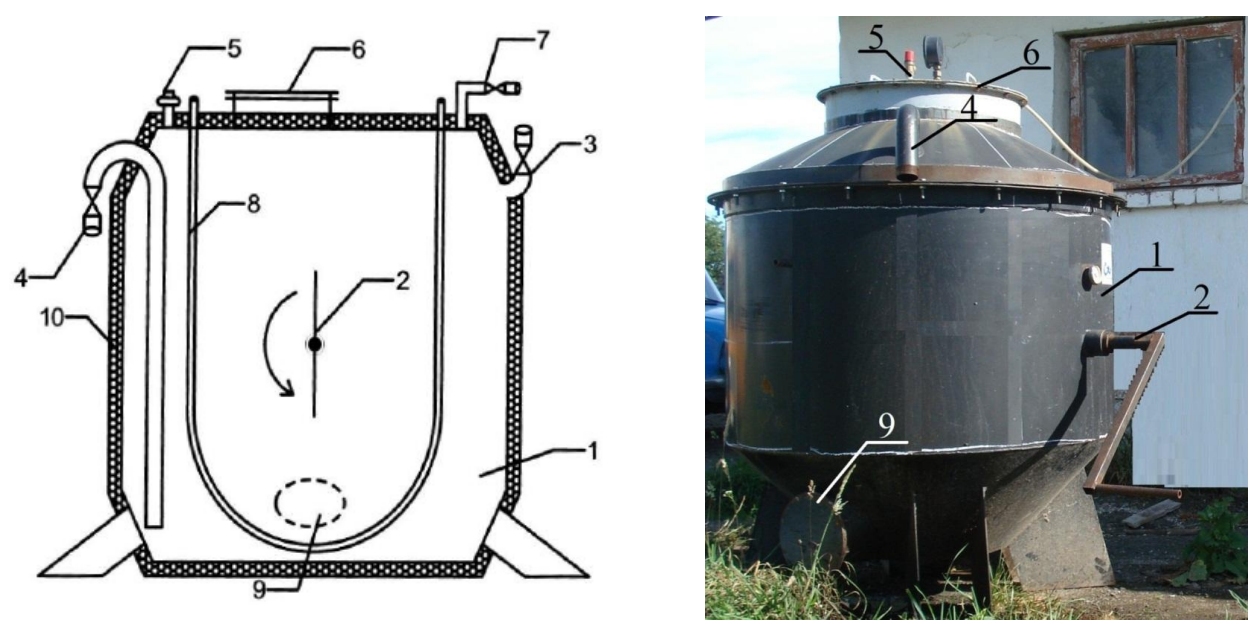

Fig. 1. Bioreactor scheme:

1 -reservoir; 2 - means of mixing; 3 -download branch pipe;

4 -discharge branch pipe; 5 -valve; 6 - hatch; 7 - biogas exit pipe;

8 - heating system; 9 - hatch; 10 - a layer of thermal insulation 
The bioreactor works as follows. The prepared straw of agricultural plants feeds through the branch pipe 3 to the reservoir 1 . Inside the reservoir 1, the biomass is mixed by means of mixing 2 and heated using a heating system 8 . To maintain the required biomass temperature, the reservoir is insulated with a layer of thermal insulation 10. After the process of anaerobic fermentation in the reservoir 1, biogas is formed, which by the biogas exit pipe 7 flows to the consumer. If necessary, excess biogas is discharged into the atmosphere through the valve 5. Exhausted straw of agricultural plants is removed through the discharge branch pipe 4. Purification and revision of the inner volume of reservoir 1 are carried out through hatches 6 and 9, if necessary. Such a construction of a bioreactor allows for efficient mixing and heating of straw of agricultural plants, which allows increase work efficiency and reduce the energy consumption of a bioreactor.

Of course, the most important characteristic of a bioreactor is the ability to produce a certain amount of biogas. It is this property, that interests engineers and potential owners of this equipment. To determine the estimated volume of biogas produced, the method of determining the volume of biogas from solid household waste and its adaptation to agricultural plant waste is used. The initial data for the calculation are the biomass temperature, ${ }^{\circ} \mathrm{C}$; biomass humidity $\mathrm{W}, \%$; ash content of dry straw of agricultural plants A, \% (Zhelykh et. al., 2019).

Calculations were performed for a bioreactor with a volume of $1.2 \mathrm{~m}^{3}$. The thermophilic temperature regime inside the bioreactor, which was maintained at $50{ }^{\circ} \mathrm{C}$, was adopted. The biomass loading of biomass was $1 \mathrm{~m}^{3}$.

Table

Biogas yield depending on the fermentation time from $1 \mathbf{m}^{3}$ of bioreactor

\begin{tabular}{|c|c|c|c|c|c|c|c|}
\hline$\tau$, days & Corn silage & $\begin{array}{c}\text { Grass } \\
\text { silage }\end{array}$ & $\begin{array}{c}\text { Rapeseed } \\
\text { silage }\end{array}$ & $\begin{array}{c}\text { Silo beet } \\
\text { leaves }\end{array}$ & $\begin{array}{c}\text { Cereal } \\
\text { silage }\end{array}$ & Clover silo & Grain silo \\
\hline 2 & 0.12 & 0.15 & 0.02 & 0.03 & 0.16 & 0.07 & 0.11 \\
\hline 5 & 1.46 & 1.76 & 0.28 & 0.38 & 1.76 & 0.90 & 1.36 \\
\hline 10 & 1.44 & 1.66 & 0.33 & 0.43 & 1.57 & 0.96 & 1.36 \\
\hline 15 & 1.25 & 1.40 & 0.32 & 0.41 & 1.29 & 0.87 & 1.18 \\
\hline 20 & 1.08 & 1.19 & 0.30 & 0.38 & 1.07 & 0.78 & 1.03 \\
\hline 25 & 0.95 & 1.03 & 0.28 & 0.36 & 0.92 & 0.70 & 0.91 \\
\hline 30 & 0.84 & 0.90 & 0.26 & 0.33 & 0.80 & 0.63 & 0.81 \\
\hline 35 & 0.75 & 0.80 & 0.25 & 0.31 & 0.71 & 0.58 & 0.73 \\
\hline 40 & 0.68 & 0.72 & 0.23 & 0.29 & 0.63 & 0.53 & 0.66 \\
\hline
\end{tabular}

The daily yield of biogas, $\mathrm{V}_{\mathrm{B}}, \mathrm{m}^{3}$, depends on the type of agricultural plants and the fermentation time $\tau$. The Table shows the value of biogas yield from corn silage, grass silage, rapeseed silage, silo beet leaves, cereal silage, clover silo and grain silo (Table).

Based on the obtained data, the maximum values of biogas yield for the above biomass were summarized in a summary diagram (Fig. 2).

As can be seen from Fig. 2, the largest amount of biogas is formed when loading raw materials every 10 days from the silage of grass and cereals, with a maximum value of $1.76 \mathrm{~m}^{3}$. The smallest amount of biogas is formed from rape silage $-0.33 \mathrm{~m}^{3}$ and silage beets $0.43 \mathrm{~m}^{3}$. 


\section{Maximum biogas yield per day from $1 \mathrm{~m}^{3}$ of bioreactor}

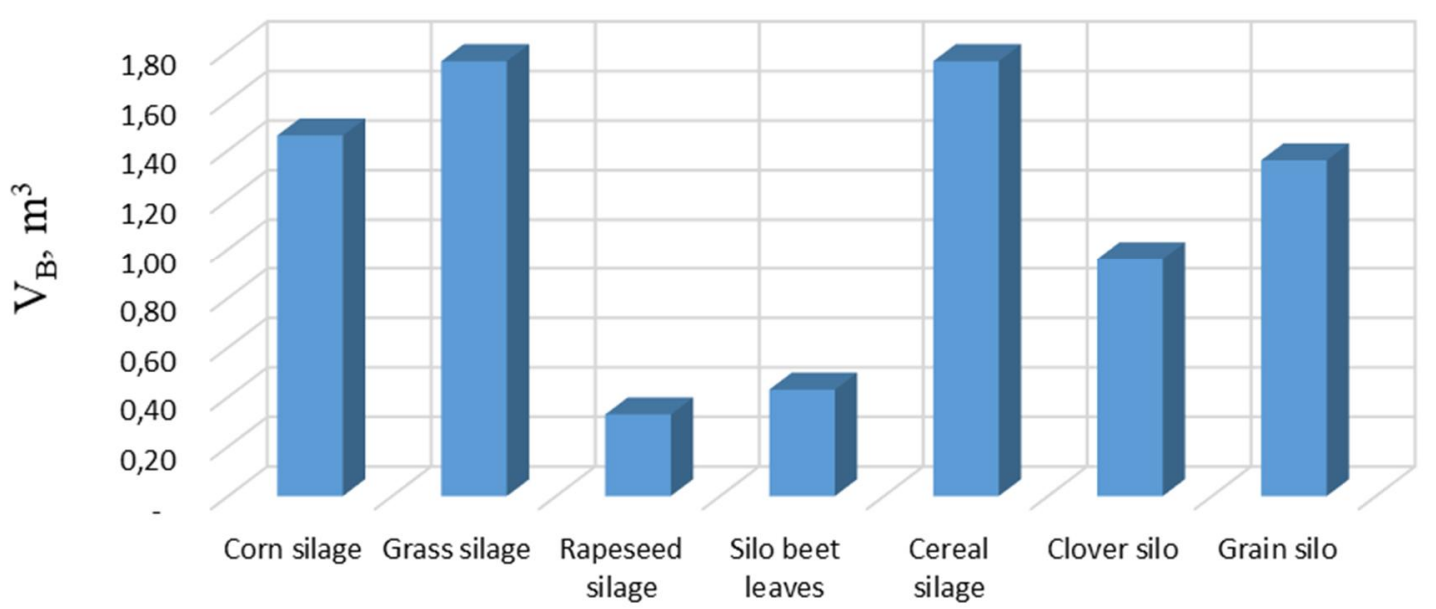

Fig. 2. The maximum daily value of biogas output from agricultural biomass, $V_{B}, m^{3}$

\section{Conclusions}

The design of a bioreactor for obtaining biogas from agricultural biomass is proposed and the amount of biogas produced in the bioreactor from different species of agricultural plants for different values of the duration of the fermentation process is determined. Studies have shown that the amount of biogas produced depends on the type of raw material, its organic and moisture component, as well as the fermentation time. The largest amount of biogas produced was obtained within 10 days from the date of loading of organic biomass. It was found that the largest amount of biogas is formed from grass and grain silage, the maximum value of which is $1.76 \mathrm{~m}^{3}$. The smallest amount of biogas is formed from rape silage $0.33 \mathrm{~m}^{3}$.

\section{References}

Chernukha, K., Dubrovskaya, V., Shklar, V. (2016). Analysis of the economic feasibility of using biomass for an agricultural enterprise. Energy: economics, technology, ecology, 2. Pages 98-104.

Savchenko, O., Zhelykh, V., Yurkevych, Y., Kozak, K., Bahmet, S. (2018). Alternative energy source for heating system of woodworking enterprise. Energy Engineering and Control Systems, 4 (1). Pages 27-30.

Litvak,O. (2015). Bioeconomic priorities in the development of the agrarian sector. Global and national problems of the economy, 8. Pages 200-205.

Soroka A. V., Kostyuchenko N. N., Bryl Ye. A., Kuznetsov I. N. (2016). Evaluation of crops and biowaste production for biogas production in the conditions of the Brest region. Ecological Herald, 2 (36). Pages 92-96 (In Russian).

Bodnar, L., Dakhnovskaya, O., Boychuk, R. (2015). Technical and ecological parameters of water boilers with power up to $1 \mathrm{MW}$ for straw burning. Scientific and technical collection "Modern technologies materials and constructions in construction”, 2. Pages 115-120.

Niedziolka, I., Szpryngiel, M. (2014). Assessment of energy consumption of pellets and briquettes production in compressing devices. Agricultural Engineering, 2 (150). Pages 145-154.

Gelotukha, G., Zhelyesna, T., Zhovmir, M., Matveev, Yu., Drozdov, A. (2011). Estimation of the energy potential of biomass in Ukraine. P. 2. Energy crops, liquid biofuels, biogas. Industrial heat engineering, 33 (1). Pages 57-64.

Panchuk, M., Shlapak, L. (2016). Analysis of prospects for the development and use of biogas in Ukraine. Exploration and development of oil and gas fields, 3. Pages 26-33.

Guangtao Wang (2010). Biogas Production from Energy Crops and Agriculture Residues. Risø-PhD-72(EN). December 2010. Pages 90. 
Perederiy, N. (2008). Getting Energy from Biogas - Prospects for Technology Development. Visnyk of the Zhytomyr State Technological University, 2 (44). Pages 281-284.

Zhelykh, V., Furdas, Yu. (2011). Patent of Ukraine No. 57360. Biogas reactor. Bul. 4. Pages 2 s.

Xue Li, Yan-Hua Liu, Xin Zhang, Chang-Ming Ge, Ren-Zhe Piao, Wei-Dong Wang, Zong-Jun Cui, and Hong-Yan Zhao. (2017). Evaluation of Biogas Production Performance and Dynamics of the Microbial Community in Different Straws. Journal of Microbiology and Biotechnology, 27(3). Pages 524-534.

Zhelykh V., Savchenko O., Furdas Yu. Kozak Kh., Myroniuk Kh. (2019). Energy potential of crop waste in heat supply systems. Theory and Building Practice, Vol 1(No. 2). Pages 37-42.

Ю. В. Фурдас ${ }^{1}$, Х. Р. Козак ${ }^{1}$, О. О. Савченко ${ }^{1}$, М. В. Луник ${ }^{1}$, М. П. Генсецький Національний університет “Львівська політехніка",

${ }^{1}$ кафедра теплогазопостачання та вентиляції,

2 Техніко-економічний коледж Національного університету “Львівська політехніка”

\section{ВИКОРИСТАННЯ СІЛЬСЬКОГОСПОДАРСЬКОЇ БІОМАСИ ДЛЯ ВИРОБНИЦТВА БІОГАЗУ}

(С Фурдас Ю. В., Козак Х. Р., Савченко О. О., Луник М. В., Генсещький М. П., 2021

Україна має значні обсяги земельних ресурсів для сільського господарства та здатна забезпечити своє населення не тільки їжею, але і сировиною для біоенергетики. Як сировина в біоенергетиці можуть бути використані відходи та сільськогосподарські залишки, які утворюються під час збирання сільськогосподарських культур та в процесі їх переробки, зокрема солома злакових культур, зернобобових культур, насіння кукурудзи та соняшнику, лушпиння соняшнику, м'якоть цукрових буряків тощо. Для енергетичних потреб біомасу безпосередньо спалюють або переробляють на тверде, рідке або газоподібне паливо.

Під час виробництва газоподібного палива із сільськогосподарських відходів утворюється не тільки джерело енергії - біогаз, але й високоякісні добрива, які можна використовувати для власних потреб чи продавати фермерським господарствам. Процес виробництва біогазу відбувається у біореакторах, конструкції яких доволі різноманітні й відрізняються за формою, матеріалом, способами змішування та нагрівання біомаси, обсягом переробки сировини.

У цій статті для виробництва біогазу із сільськогосподарської біомаси запропоновано конструкцію біореактора, що дає змогу ефективно змішувати та прогрівати органічну сировину для підвищення ефективності роботи біореактора та збільшення виходу біогазу.

Аналітичні дослідження показали, що кількість виробленого біогазу залежить від виду сировини, їі органічної та вологісної складової, а також часу бродіння. Найбільшу кількість виробленого біогазу отримано протягом 10 днів з дати завантаження органічної біомаси. Встановлено, що максимальна кількість біогазу утворюється із трав'яного та зернового силосу, вихід біопалива становить 1,76 м $^{3}$. Найменша кількість біогазу утворюється 3 ріпакового силосу $-0,33 \mathrm{~m}^{3}$, а також силосного бурякового листя - 0,43 $\mathrm{m}^{3}$.

Ключові слова: біомаса, біогаз, біореактор, сільськогосподарська біомаса, час бродіння, біоенергія. 